\title{
Economics of organic and inorganic jaggery production in Kolhapur district of Maharashtra
}

Received : 03.06.2017; Revised : 19.08.2017; Accepted : 03.09.2017

\begin{abstract}
A research was conducted in Karaveer and Panhala tahsils of Kolhapur district of Maharashtra to study the economics of organic and inorganic jaggery production in 2011-12. The study revealed that the per unit resource use and their cost was estimated to Rs. 679483.24 and Rs.3240745.98 in respect of organic and inorganic jaggery processing unit, respectively. It is interesting to note that the cost on account of resource use was found more in inorganic jaggery than organic jaggery production, this may be due to the crushing days of organic jaggery units was much less than that of inorganic jaggery production also complete absence of hydrous powder and very less use of phosphoric acid in case of organic jaggery. It is also revealed that the per quintal cost of jaggery production was Rs. 2768.97 and Rs. 2834.31 for organic and inorganic jaggery, respectively.The per unit establishment cost for organic and inorganic jaggery was Rs. 806120 and Rs. 808509, respectively. This implied that the establishment cost was observed more or less similar in both the type of jaggery production. The per quintal cost of jaggery processing was less for organic (Rs. 2768.97) than the inorganic jaggery (Rs. 2834.31) this was due to higher cost of chemicals which required in inorganic jaggery production. The per quintal net profit was highest in organic than inorganic jaggery production. This was due to very less cost of chemicals and more net return per quintal prices obtained. The Break-even point for organic and inorganic jaggery production in physical terms was 247.68 qtls. and 337.97 qtls., in monitory terms it was Rs. 891646 and Rs. 1115300, respectively. The chemical cost had negative affect on net price received per quintal of jaggery.
\end{abstract}

KEY WORDS : Capital investment, Cost of production, Breakeven analysis, B:C ratio, Multiple regression analysis

How to cite this paper : Malkunje, N.M., Lembhe, J.V. and Kharat, H.V. (2017). Economics of organic and inorganic jaggery production in Kolhapur district of Maharashtra. Internat. J. Com. \& Bus. Manage, 10(2) : 129-138, DOI: 10.15740/HAS/IJCBM/10.2/129-138.

\section{MEMBERS OF THE RESEARCH FORUM}

Correspondence to:

N. M. MALKUNJE, Department of Agricultural Economics and Statistics, College of Agriculture, KOLHAPUR (M.S.) INDIA

Email : nasroddin786@gmail.com

\section{Authors' affiliations:}

J.V. LEMBHE, Department of Agricultural Economics and Statistics, Shreemant Shivajiraje College of Horticulture, Phaltan, SATARA (M.S.) INDIA

Email:jayeshlembhe@ gmail.com

H.V. KHARAT, Department of Agricultural Economics and Statistics, College of Agriculture, KOLHAPUR (M.S.) INDIA

Email:kharathanumant@rediffmail.com 